Vol. 44, N. 3 : pp. $303-311$, September, 2001

ISSN 1516-8913 Printed in Brazil

\title{
Anatomical Confirmation of Root Parasitism in Brazilian Agalinis Raf. Species (Scrophulariaceae)
}

\author{
Samira Ismael Elias ${ }^{1}$, Vinicius Castro Souza ${ }^{2}$ and Beatriz Appezzato-da-Glória ${ }^{2 *}$ \\ ${ }^{1}$ UNICAMP. Bolsista da FAPESP; ${ }^{2}$ Departamento de Ciências Biológicas, Escola Superior de Agricultura "Luiz de \\ Queiroz", Universidade de São Paulo, Caixa Postal 09, 13418-900, Piracicaba, SP, Brasil. Bolsista de Pesquisa do \\ $C N P q$
}

\begin{abstract}
Agalinis Raf. consists approximately of 60 species, 14 of which occur in Brazil. The genus presents predominantly american distribution and the Brazilian species appears mainly in high areas of Minas Gerais. The North-American species are refered as hemiparasites, but there is no anatomical data about it in relation to the Brazilian species. Anatomical studies were conducted to verify whether the Agalinis species from Brazil were root parasites or not. The eight species analysed were presented haustoria which varied in shape, arrangement and size. They were generally elliptic or globose structures and mostly were tightly sticked to other roots in a solitary or clustered manner. The seriate sections of haustoria showed that there was a xylem connection between them and the roots in which they were attached. This fact has confirmed for the first time the occurrence of parasitism in the Brazilian species of Agalinis.
\end{abstract}

Key words: Haustorium, hemiparasitism, vascular connection, root host

\section{INTRODUCTION}

Scrophulariaceae comprises about 190 genera and 4000 species with its centre of diversity in temperate regions of the north hemisphere (Cronquist, 1980). Agalinis Raf., comprises approximately 60 species, including annual and perennial herbs to shrubs. The genus occurs from the coastal plain of Nova Scotia, in Canada, to the Puna communities above $3000 \mathrm{~m}$ in the Andes Mountains of South America. The North and Central America are represented by about 35 species and South America there are approximately 25 species (Canne-Hilliker, 1988). From these 25 species in South America, 14 occur in Brazil.

Most of the Brazilian species occur in Southeast and South, mainly in areas of campos rupestres in Minas Gerais state. In spite of occurring mostly in restricted areas, one of the species has a large distribution, appearing since the Antilles region until $20^{\circ} \mathrm{S}$ of latitude.

Most anatomical studies on parasitic Scrophulariaceae during the first part of the twentieth century were tangential to taxonomic or ecological studies. Between 1930 and 1950 few papers on parasitic Scrophulariaceae appeared and since 1960 there has been a resurgence of interest in these plants (Musselmann \& Dickison, 1975).

Malcolm (1966) reported that the majority of chlorophyllous parasites belonged to the Scrophulariaceae and Santalaceae. They included herbs, shrubs and trees which rarely looked any different from autotrophic plants and the parasitism of them went unsuspected for 60 years after the publication of the first account of root parasitism.

\footnotetext{
*Author for correspondence
} 
Cases of parasitism were related in several genera of Scrophulariaceae. Kuijt (1969) documented a lot of them as root parasites: Agalinis (NorthAmerican species), Alectra, Aureolaria, Bartsia, Buchnera, Buttonia, Castilleja, Cordylanthus, Dasistoma, Euphrasia, Harveya, Hyobanche, Lathraea, Macranthera, Melampyrum, Melasma, Orthantha, Orthocarpus, Pedicularia, Rhamphicarpa, Rhinanthus, Schwalbea, Seymeria, Siphonostegia, Sopubia, Striga and Tozzia.

Although there exists many references about parasitic Scrophulariaceae in the world, in Brazil there are few studies in this area, limited to a few statements without anatomical basis. Brade (1935) mentioned Nothochilus Radlk. and Magdalenaea Brade as root parasites pointing out the presence of nodules on their roots. These nodules have been often seen in populations of Esterhazya splendida J.C. Mikan present in Serra do Cipó, Minas Gerais (Souza, 1990) and may be similar to those noticed by Brade (1935). Nevertheless, anatomical data does not exist to confirm such information. In the several attempts to cultivate any genus of the subfamily Rhinanthoideae, such as Agalinis Raf., Escobedia Ruiz \& Pav., Esterhazya J.C. Mikan and Physocalyx Pohl, it was not obtained any lasting success. This suggested that survival of these species depended on the presence of the host (Souza, 1996). Several works deal with the genus Agalinis under the parasitic aspect even from the anatomical point of view. However, these studies have been made only to the North-American species of Agalinis and no statements exist to the Brazilian species. Souza (1996) referred the Brazilian species of Agalinis as probably root parasites, since this fact is widely known to the North-American species (Pennell, 1929).

Thus, considering the absence of precise information about parasitism to the Brazilian species of Agalinis, we conducted an anatomical study in order to verify whether these plants have a parasitic habit or not. Once such species are common in areas of campos rupestres, such information will be assist an understanding of ecological interactions in this ecosystem. Survival will also preserve biodiversity, since several species are endemic. Confirming the parasitic habit, maybe the only way to preserve these species is "in situ". Considering that parasitic Scrophulariaceae could cause great damage to world agriculture the information derived here would be an important from this point of view as well.

\section{MATERIALS AND METHODS}

Roots of eight species of Agalinis were studied in order to verify the existence of haustoria: $A$. angustifolia (Mart.) D’Arcy, A. bandeirensis Barringer, A. aff. brachyphylla (Cham. \& Schltdl.) D'Arcy, A. communis (Cham. \& Schltdl.) D'Arcy, A. genistifolia (Cham. \& Schltdl.) D'Arcy, A. glandulosa (G.M. Barroso) V.C. Souza \& S.I. Elias, A. itambensis V.C. Souza \& S.I. Elias and A. nana S.I. Elias \& V.C. Souza. Field trips were made between December of 1997 and September of 1999 according to the species flowering period: 1) December/1997 in Itararé (SP); 2) February/1998 in Parque Nacional do Caparaó (MG); 3) April/1998 in Diamantina (MG), Santo Antônio do Itambé (MG) and Serra do Cipó (MG); 4) February/1999 in Curitiba (PR); 5) March/1999 in Parque Nacional da Serra da Canastra (MG); 6) May/1999 in Catolés (BA), Diamantina (MG) and Serra do Cipó (MG), 7) September/1999 in Corumbá, Pantanal (MS).

The plants were collected in the field with a clod which contained the roots. At the laboratory, the clods were carefully washed and analysed using the stereoscope microscope to identify and photograph the haustoria. As the samples were obtained under field conditions, the haustoria development stages were not known.

The root samples selected were fixed in FAA 50 (Sass, 1951), dehydrated through a graded alcoholic-ethyl series and submitted to the vacuum pump. After that they were included in glycol methacrylate resin of Reichert-Jung. For the anatomical studies, seriate sections were made at 6 $\mu \mathrm{m}$ thick; the samples were stained with toluidine blue $0,05 \%$ phosphate buffer and citric acid $\mathrm{pH}$ 4,0-6,0 (Sakai, 1975) and affixed to glass slides with synthetic resin "Entellan".

Transversal sections of the host roots were made in order to compare them to the Agalinis root sections. All the sections were documented by photomicrographs.

\section{RESULTS AND DISCUSSION}

The roots analysed by the stereoscope microscope contained structures similar to nodules, which varied in shape, arrangement and size (figures 14). They were generally elliptic or globose structures and most of the time they were tightly 
sticked to other roots in a solitary or clustered manner. In some species they were produced close together in a bead-like fashion, such as $A$. genistifolia (figure 3) and A. nana.

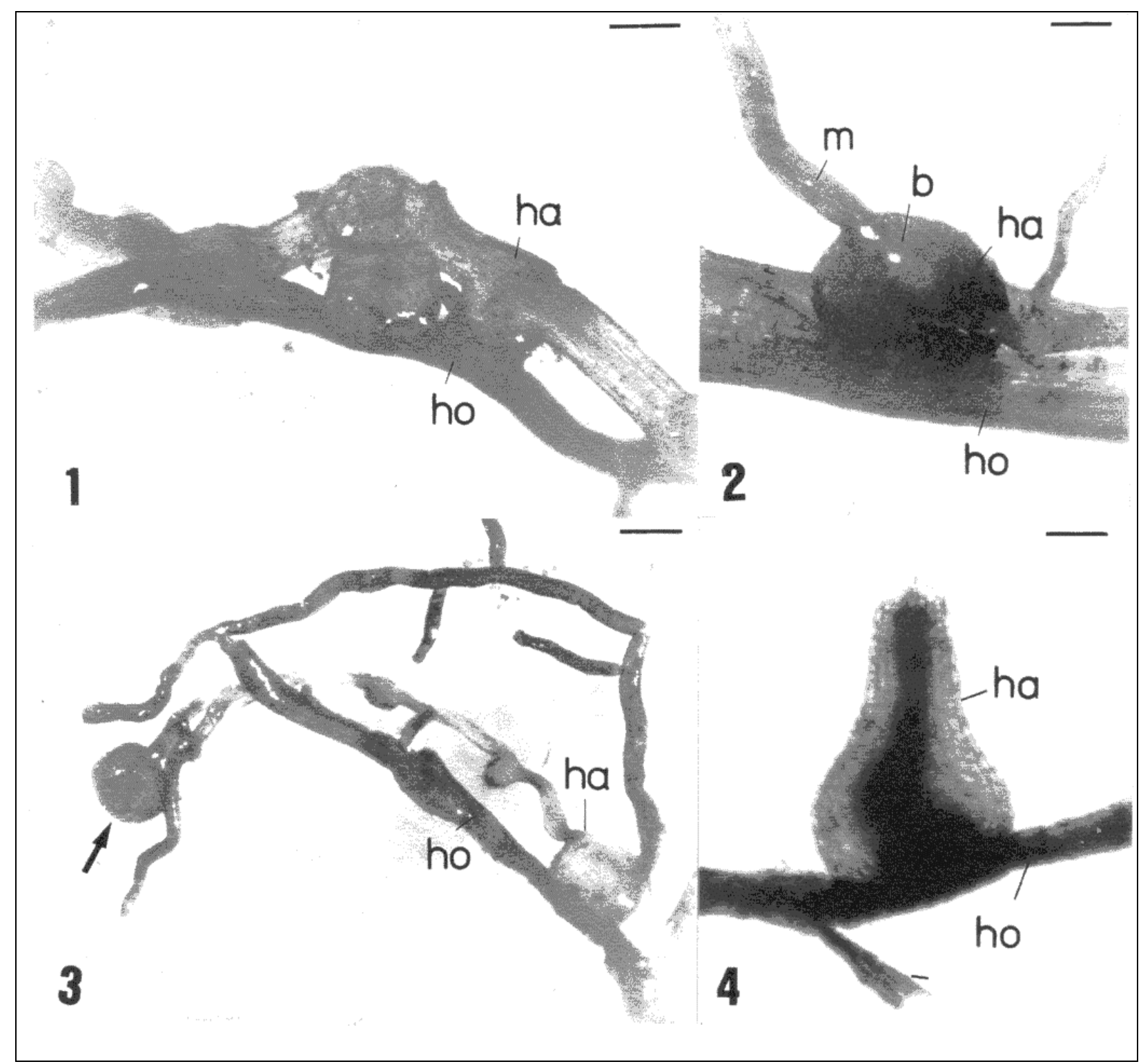

Figures 1-4 - Agalinis haustoria sticked to host roots; haustorium (ha); host (ho); 1: Clustered haustoria of $A$.

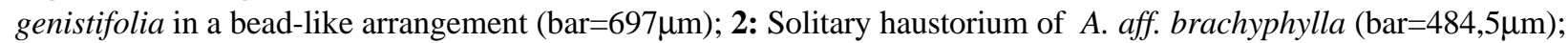
haustorium body (b); haustorium's mother-root (m); 3: Terminal haustorium of A. genistifolia (arrow) (bar=969 $\mu \mathrm{m})$; 4: Solitary haustorium of A. glandulosa in terminal position (bar=297,5 $\mu \mathrm{m}$ ).

The general morphology of these nodules was very similar to the haustoria morphology found in the North-American species of Agalinis studied by Musselmann \& Dickison (1975). The authors referred to the mature haustorium as a bell-shaped to globose structure, although this shape might be altered when sandwiched between host roots and other obstacles. Piehl (1963), studying the parasitism in Pedicularis canadensis L., also encountered haustorial structures similar to the nodules as observed by us. He described the Pedicularis haustoria as nearly globose to broadly elliptic structures and noticed the presence of haustoria produced close together in a bead-like arrangement, like the haustoria of A. genistifolia and A. nana. In Cordylanthus, Chuang \& Heckard 
(1971) also noticed haustoria produced close together in a bead-like arrangement.

In general, the nodules were produced from fine rootlets of Agalinis and were identified most of the times only by means of a stereoscope microscope. However, there were several samples visible even macroscopically, which reached $3 \mathrm{~mm}$ long.

The nodules of all the species arised laterally on the Agalinis roots (figures 1-4). In A. itambensis, A. bandeirensis, A. aff. brachyphylla, A. communis, A. genistifolia and A. glandulosa we also verified that some nodules appeared in terminal position (figures 3 and 4) which were attached to some root or not. According to Piehl (1963), a possible explanation to the terminal position of haustoria would be that the portion of the root developing beyond the haustorium sometimes aborts, and could deteriorate and drop off, giving the appearance of being terminal.

The roots attached to the nodules were always located by their lateral portion and none of them were connected by apical portion (figures 1-4). It has been mentioned that the nodules-bearing Agalinis roots were often perpendicular or parallel to the roots in which they were attached to, although they could also be connected at any angle.

The anatomical analysis of the nodules showed a xylem connection between them and the roots in which they were attached (figures 7, 11 and 12). Once the nodules were really haustoria, we adopted a specific nomenclature to describe their morphology and anatomy. The terminology used here was based mainly on Musselmann \& Dickison (1975).

We could distinguished two general regions of the Brazilian Agalinis haustorial structure: the swollen portion which kept fixed to the host root and a segment of root that gave rise to this swollen portion (figure 2). Following Fineran (1963), these two regions are called respectively the body and the parent (mother) root of the haustorium.

The haustoria had an epidermis with one layer of cells more or less rounded, similar to the cortex cells. At the contact region between the haustorium and the host root the epidermal cells were differentiated from the others by being longer, in a palisade-like arrangement (figure 10, arrow). These cells were present in all the species studied, but in Agalinis bandeirensis they were not observed at the contact region but only at the endophyte. Several other parasitic genera from Scrophulariaceae and species of other families are also similar to the Brazilian species of Agalinis in relation to those cells. These palisade cells from the contact region were also observed by Malcolm (1966), who recognised collunar cells close to host roots in Castilleja coccinea (L.) Spreng. (Scrophulariaceae). Dobbins \& Kuijt (1969), studying the parasitism in Pithirusa pyrifolia (H.B.K.) Eichl. (Loranthaceae), refered that these cells expand longitudinally extending finger-like projections towards the host. Cells with the same features also appear in Agalinis linifolia (Nutt.) Britton haustoria (Musselmann \& Dickison, 1975). Recently they were also mentioned and discussed in studies about Struthanthus vulgaris Mart. (Loranthaceae) and were called adhesive disc by Monteiro et al. (1996).

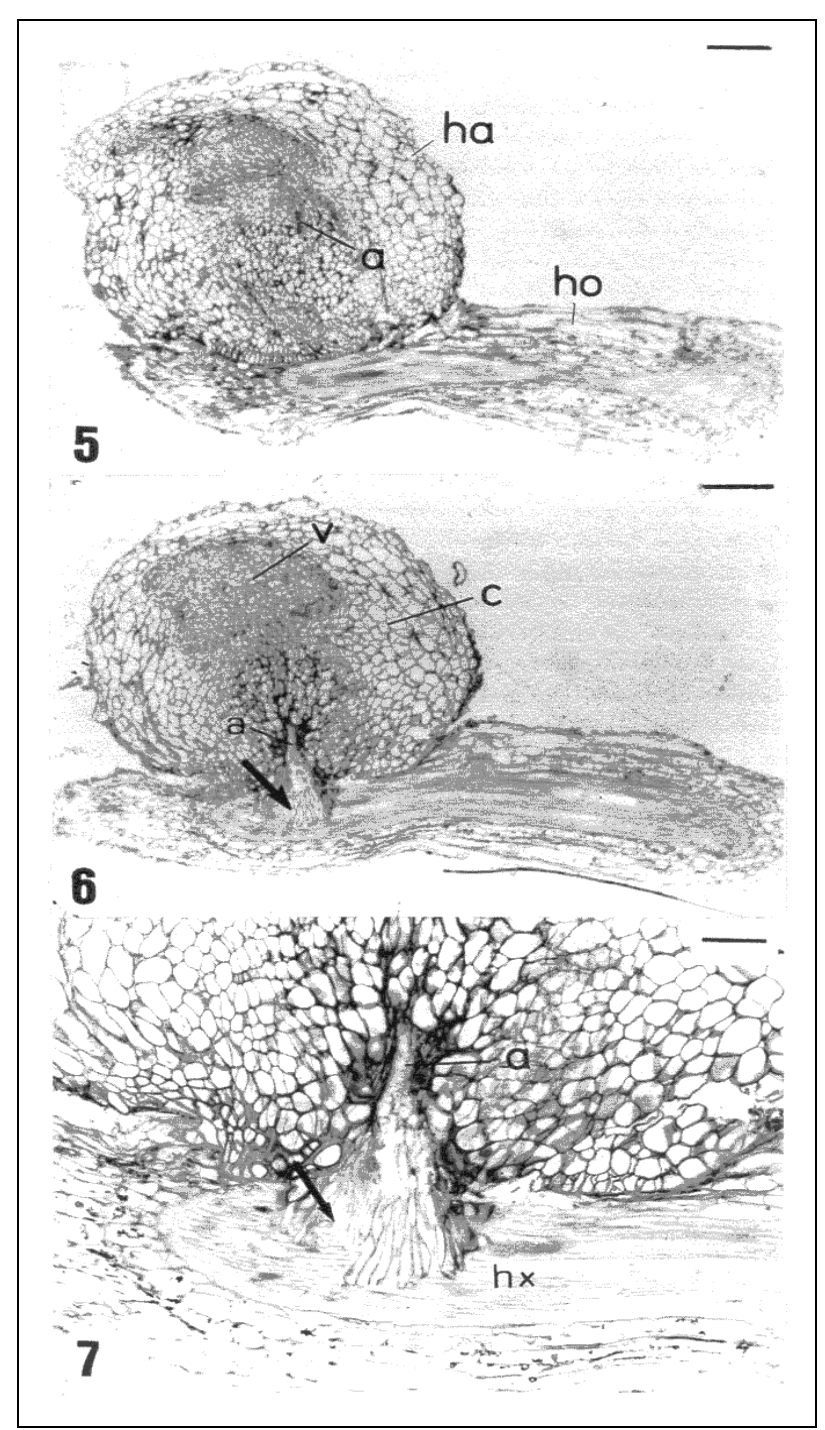

Figures 5-7 - Longitudinal seriate sections of the Agalinis genistifolia haustorium parasiting a monocotyledon host root; haustorium (ha); host root (ho); vascular core (v); cortex (c); axial strands (a); host xylem (hx); vascular connection between the haustorium and the host (arrow) (bar=215 $\mu \mathrm{m}) ; 5$ and 6

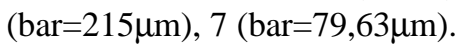


The cortex of the haustorium was composed of isodiametric cells with thin walls and it always assumed an outlying position in the haustorium body (figure 6). In some cases, like in Agalinis itambensis, the cortex encompassed the host root. This fact was also noticed by Piehl (1963) for the Pedicularis canadensis haustoria.

Approximately at the centre of the haustorium there existed a vascular region provided with tracheary elements, interspersed or not with parenchyma cells (figures 6, 8 and 9). This region is called vascular core by Musselmann \& Dickison (1975). Surrounding the vascular core there are cells with a meristematic aspect resembling a vascular cambium (figure 8 and 9), which could become continuous with the parent root cambium. Between the vascular core and the contact zone with the host existed a region composed by smaller cells which were in a compact arrangement provided with more evident nucleus than the cortex cells (figure 11). Following Rogers \& Nelson (1962), this area has been called nucleus and is laterally delimited by the cortex (figure 12).

Among the nucleus cells there were tracheary elements establishing the xylem continuity between the host root vascular cylinder and the haustorium vascular core (figure 13). They were called axial strands by Stephens, 1912 (apud Musselmann \& Dickison, 1975) and probably arise from the meristematic cells differentiation at this region.

The axial strands consisted of tracheary elements which varied in thickness, that is, in number of vessel element rows per strand. They were generally made up of only one row of tracheary elements (figure 11, arrow), but they could become wider as they approached the host root (figure 7, arrow). The strands tracheary elements generally differed from the vascular core xylem cells by being longer than wide.

Kuijt (1969) called endophyte the portion of haustorial tissue that penetrateed into the host tissue. For the Agalinis species studied here, the endophyte was made up of parenchyma cells and tracheary elements. The elongate parenchyma cells of endophyte were probably the same cells of the contact region. Sieve elements sometimes were present near the vascular core, but not at the contact region indicating that the connection occurred only through the xylem. This indicated that the parasite probably depended on the host for water (except the genera which lack chlorophyll) what has been a very well-known fact in parasitic members of Scrophulariaceae (Musselmann \& Dickison, 1975). In spite of this, studies about Striga asiatica (L.) Kuntze (Rogers \& Nelson, 1962) and Odonties verna (Bell.) Dum. (Govier et al., 1967) have demonstrated transport of organic material from host to chlorophyllous parasite, even though when sieve elements were absent.

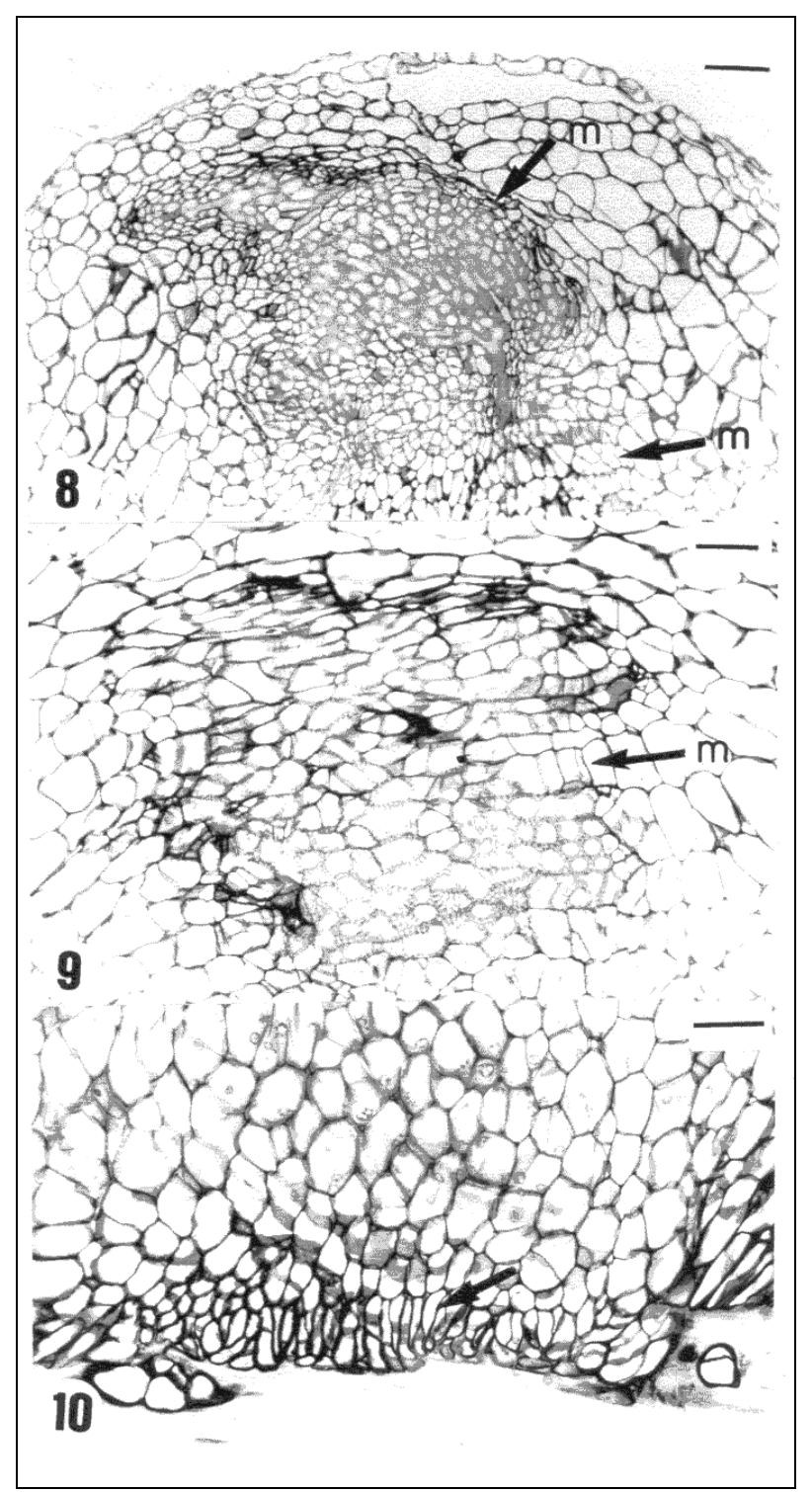

Figures 8-10 - Agalinis haustoria anatomy in detail. 8 and 9: Cambium like meristem (m) around the vascular core in A. genistifolia and A. communis (arrows); 10: Cells of the contact region in A. communis (arrow); 8 and 9 (bar=39,82 $\mu \mathrm{m}), 9$ (bar=79,63). 


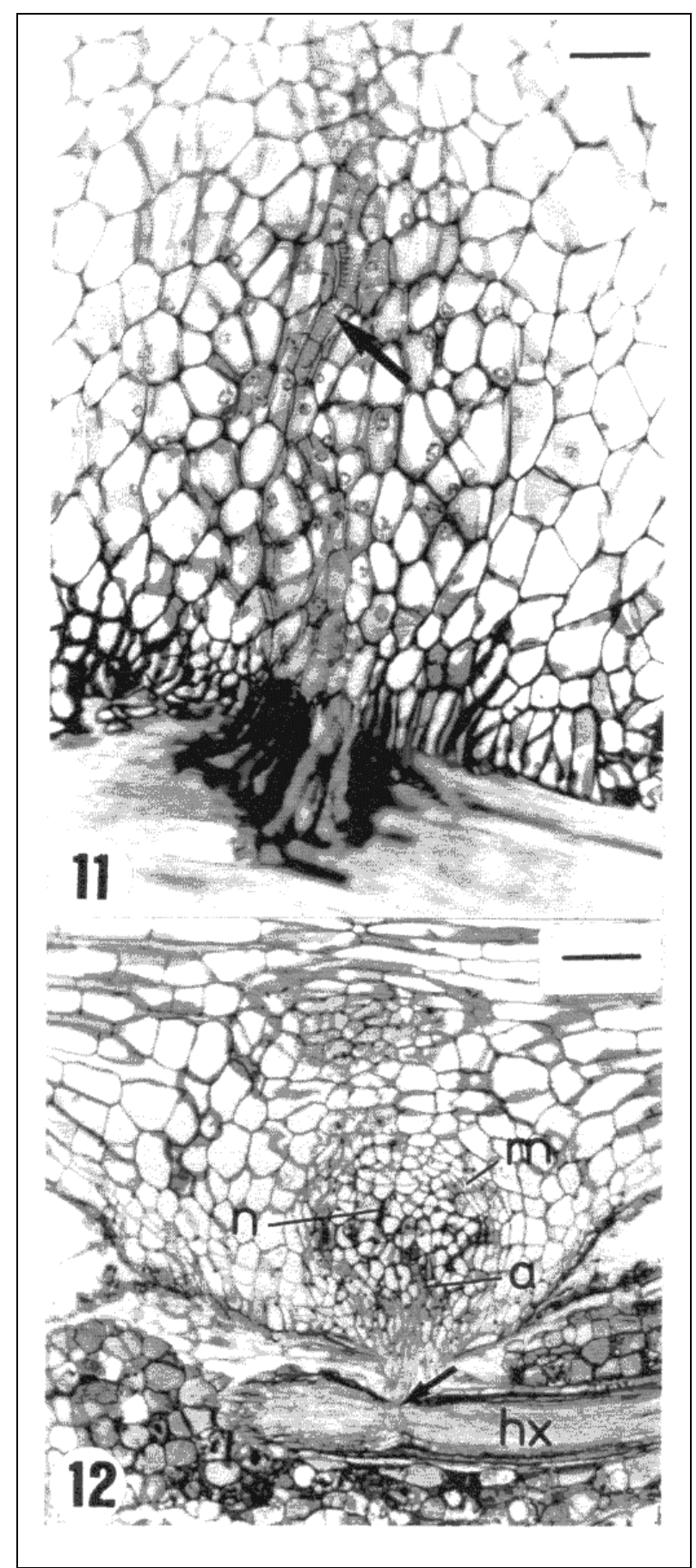

Figures 11-12 - Agalinis haustoria anatomy in detail. 11: Nucleus of A. communis. Note the axial strands establishing the continuity with the host root (arrow) (bar=39,82 $\mu \mathrm{m}$ ); 12: Vascular connection between $A$. bandeirensis haustorium and a monocotyledon host root; host root xylem (hx); nucleus (n); axial strands (a); cambium like meristem (m) around the nucleus; vascular connection (arrow) (bar=79,63 $\mu \mathrm{m})$.
Some Agalinis roots were in primary stage of growth. They were protostelic with few xylem ridges (figure 13). Some of them were in secondary stage of growth (figure 14). A. angustifolia, A. genistifolia and A. itambensis present fungi hyphae into the cortex cells (figure 13, arrow) indicating a mycorrhizal association. In Agalinis aphylla (Nutt.) Raf. (North American species), Musselmann \& Dickison (1975) noticed that the haustorial attachment to host roots took place in the vicinity of coralloid mycorrhizal roots. The majority of host roots presented typical anatomical features of monocotyledoneae roots. They were polyarch and siphonostelic roots (figures 15 and 16). The high frequency of monocotyledon roots as Agalinis hosts did not necessarily mean that there was selectivity by host species. One of the reasons why the monocotyledoneae appeared in high frequency was the fact that the majority of the plants occurring around the Agalinis plants were mainly grasses. 


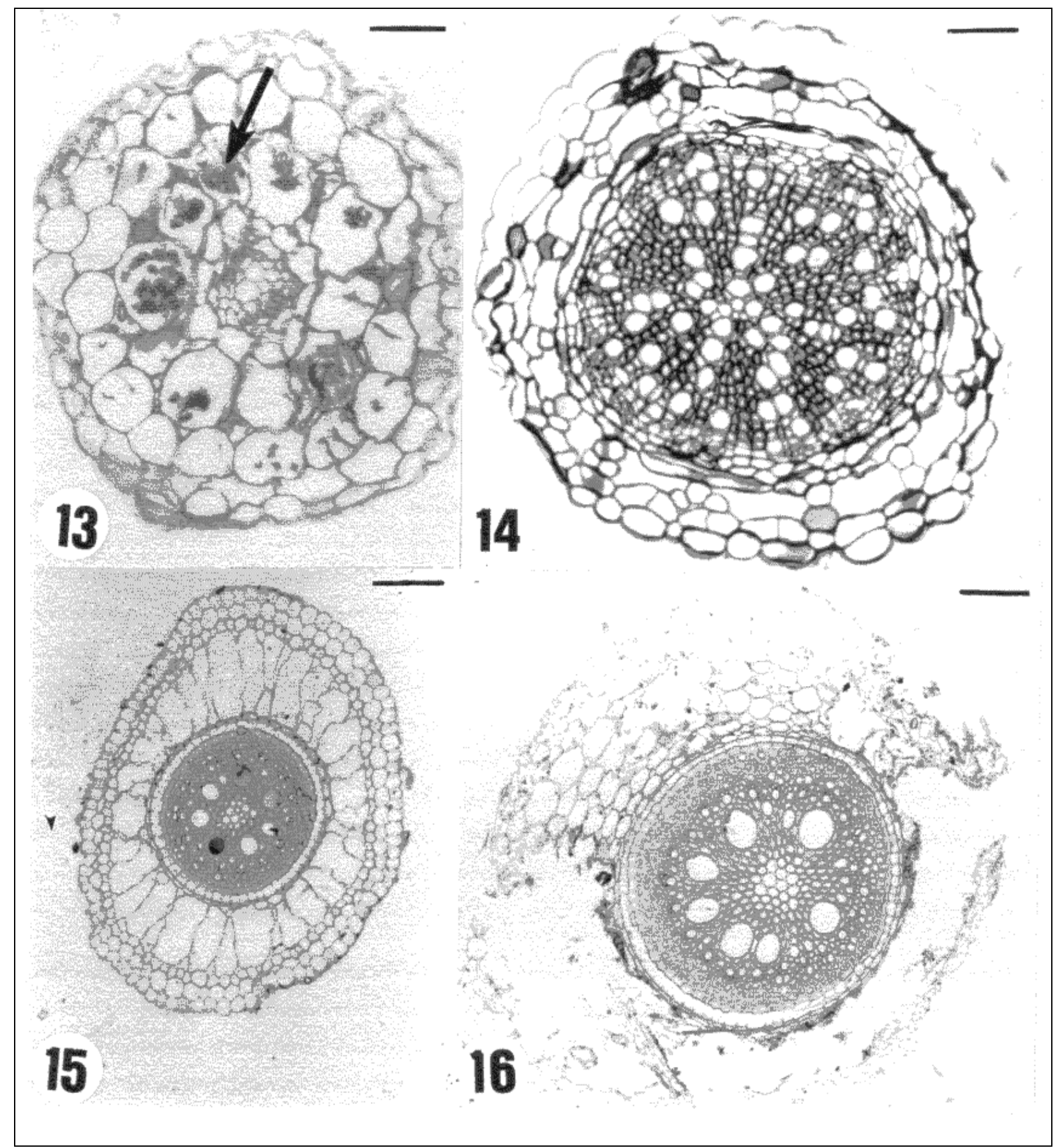

Figures 13-16 - Transverse sections of Agalinis roots and host roots. 13: A. genistifolia root in a primary stage of growth. Note the presence of fungi hyphae into the cortex cells (arrow) (bar=51 $\mu \mathrm{m}) ; 14:$ A. communis root in a secondary stage of growth (bar=39,82 $\mu \mathrm{m})$; 15: A monocotyledon host root parasited by A. communis (bar=39,82 $\mu \mathrm{m})$; 16: A monocotyledon host root parasited by A. genistifolia (bar=79,63 $\mu \mathrm{m}$ ).

Some studies about parasitism have drawn attention to the great variety of host species of North-American Agalinis species. Pennell (1928) showed that the annual species of Agalinis parasite a great variety of Angiospermae. Among the hosts it could be found since Poaceae until Asteraceae.
He observed that the perennial species (A. linifolia (Nutt.) Britton) parasite only Pinus species. Musselmann \& Mann (1977) however, observed that this species included other genera as hosts and not only Pinus. They also showed that in general, the North-American species of Agalinis have a lot 
of hosts and their roots can connect almost with any neighbouring root. They drew attention to the fact that the amount of hosts could expand considerably if more field studies were made.

The anatomy of some host roots of $A$. angustifolia was very similar to the Agalinis roots anatomy, suggesting the occurrence of self-parasitism (when haustoria parasite roots of the same individual) or intra-specific parasitism (when haustoria parasite other individual from the same species). These two kinds of parasitism have already been related by some authors in several genera of Scrophulariaceae, such as Atsatt \& Strong (1970), Govier et al. (1967), Musselmann \& Dickison (1975) and Piehl (1963). Musselmann \& Dickison (1975) observed this sort of parasitism in several genera, like Aureolaria, Dasistoma, Euphrasia, Macranthera and Melampyrum, besides one species of Agalinis (A. linifolia).

Self-parasitism also is known in species of other families. Fineran (1965), studying Exocarpus bidwilii (Santalaceae) suggested that seeds provided from the parasite plant could germinate close to the mother-plant and produced haustoria on their own roots until the seedlings were able to connected themselves to roots from other species. This mechanism perhaps occurs in Scrophulariaceae. Piehl (1963) observed in Pedicularis canadensis self-parasitism or intraspecific parasitism that occurred specially where several seedlings grew very close to one another. In spite of this, there was no seedlings next to $A$. angustifolia plants collected.

\section{RESUMO}

Agalinis Raf. (Scrophulariaceae) consiste de aproximadamente 60 espécies, das quais 14 ocorrem no Brasil. O gênero apresenta distribuição predominantemente americana, e as espécies brasileiras ocorrem principalmente em áreas de altitude de Minas Gerais. As espécies NorteAmericanas de Agalinis são referidas como hemiparasitas, mas não há dados anatômicos sobre este fato em relação às espécies brasileiras. Neste sentido, este trabalho apresenta estudos anatômicos com a finalidade de verificar se as Agalinis do Brasil são parasitas ou não. As oito espécies analisadas aqui apresentam haustórios que variam em forma, arranjo e tamanho. Geralmente são estruturas elípticas ou globosas e na maioria das vezes encontram-se firmemente aderidas a outras raízes de maneira solitária ou agrupada. Os cortes seriados dos haustórios revelam que há uma conexão xilemática entre eles e as raízes às quais estão conectados. Este fato confirma pela primeira vez a ocorrência de parasitismo nas espécies brasileiras de Agalinis.

\section{ACKNOWLEDGEMENTS}

We are grateful to Hatschbach, Jimi Nakajima, Wagner de Lima Moreira, Lúcio Leoni, Vali and Arnildo Pott, Glauco de Souza Rolim, Juliana de Paula Souza, Wellington Forster and Lindolpho Capellari Junior for their help with field work. We also thank Marli Soares for technical assistance and FAPESP for financial support.

\section{REFERENCES}

Atsatt, P. R. and Strong, D. R. (1970), The population biology of annual grassland hemiparasites. I. The host environment. Evolution, 24, 278-291

Brade, A. C. (1935), Um novo gênero de Scrophulariaceae. Arq. Inst. Biol. Veget,. 1(3), 235240

Canne-Hilliker, J. M. (1988), Agalinis (Scrophulariaceae) in Peru and Bolivia. Brittonia, 40(4), 433-440

Chuang, T. I. and Heckard, L. R. (1971), Observations on root-parasitism in Cordylanthus (Scrophulariaceae). Amer. J. Bot., 58(3), 218-228 Struthanthus vulgaris Mart. (Loranthaceae). Revta Brasil. Bot., 19(1), 25-34

Cronquist, A. (1981), An integrated system of classification of flowering plants. Houghton University Press, New York, 920-980

Dobbins, D. R. and Kuijt, J. (1974), Anatomy and fine structure of the misteltoe haustorium (Phthirusa pyrifolia). I. Development of the young haustorium. Amer. J. Bot., 61(5), 535-543

Fineran, B. A. (1963), Studies on the root parasitism of Exocarpus bidwillii Hook. f. II. External morphology, distribution and arrangement of haustoria. Phytomorphology, 13, 30-41

Fineran, B. A. (1965), Studies on the root parasitism of Exocarpus bidwillii Hook. f. VI. Haustorial attachment and the phenomenon of self-parasitism. Phytomorphology, 15, 387-399

Govier, R. N. et al., (1967), Hemiparasitic nutrition in Angiosperms. New Phytol., 66, 285-297

Kuijt, J. (1969), The biology of parasitic flowering plants. University of California Press, Berkeley. 81-103 
Malcolm, W. (1966), Root parasitism of Castilleja coccinea. Ecology, 47(2), 179-186

Monteiro, W. R. et al., M. (1996), Anatomical and histochemical aspects of the primary haustorium of Struthanthus vulgaris Mart. (Loranthaceae). Revta Brasil. Bot., 19(1), 25-34

Musselmann L. J. and Dickison, W. C. (1975), The structure and development of the haustorium in parasitic Scrophulariaceae. Bot. J. Linn. Soc., 70, $183-212$

Musselmann, L. J. and Mann, W. F. Jr. (1977). Host Plants of Some Rhinanthoideae (Scrophulariaceae) of Eastern North America. Pl. Syst. Evol., 127(1), 45-53

Pennell, F. W. (1928), Agalinis and allies in North America. I. Proceedings of the academy of natural sciences of Philadelphia, 80, 339-448

Pennell, F. W. (1929), Agalinis and allies in North America, II. Proceedings of the academy of natural sciences of Philadelphia, 81, 111-247

Piehl, M. A. (1963), Mode of attachment, haustorium structure, and hosts of Pedicularis canadensis. Amer. J. Bot., 50, 979-985
Rogers, W. E. and Nelson, R. R. (1962), Penetration and nutrition of Striga asiatica. Phytopathology, 52, 1064-1070

Sakai, W. S. (1975), Simple method for differential staining of paraffin embedded plant material using toluidine blue O. Stain Technology, 48(5), 247-259

Sass, J. E. (1951), Botanical microtechnique. Ames: Iowa State University, 228

Souza, V. C. (1990), Scrophulariaceae da Serra do Cipó, Minas Gerais, Brasil. MsC Thesis, Instituto de Biociências, Universidade de São Paulo, Brazil

Souza, V.C. (1996), Levantamento das espécies de Scrophulariaceae nativas do Brasil. Doctorate Thesis, Instituto de Biociências, Universidade de São Paulo, São Paulo, Brazil

Received: February 20, 2000; Revised: April 14, 2000; Accepted: November 22, 2000. 